\title{
BACTERICIDAL ACTIVITY OF SERUM FROM CYSTIC FIBROSIS PATIENTS FOR PSEUDOMONAS AERUGINOSA
}

\author{
A. R. L. Penketh, T. L. Pitt*, Margaret E. Hodson and J. C. Batten \\ Cardiothoracic Institute, Brompton Hospital, Fulham Road, London SW3 6HP, and \\ *Division of Hospital Infection, Central Public Health Laboratory Service, Colindale \\ Avenue, London NW9
}

\begin{abstract}
SUmmaRY. The bactericidal action of serum from 61 adult patients with cystic fibrosis (CF) against autologous and heterologous strains of Pseudomonas aeruginosa has been studied. CF serum had a similar bactericidal action to normal human serum (NHS) against a reference panel of strains. Six CF sera had a selective inability to kill autologous strains of pseudomonas, which were sensitive to NHS and to sera from other CF patients. The six sera had normal levels of complement and immunoglobulin and were bactericidal to other strains. A titratable blocking factor was present in these sera and it interfered with the bactericidal action of NHS on the appropriate strain. This factor was present in the IgG-containing fractions of serum obtained by ionexchange chromatography, but was not removed from the serum by absorption with the pseudomonas strain. Some CF sera may fail to kill sensitive strains of pseudomonas because of the development of a blocking IgG antibody against naturally occurring bactericidal IgM antibody.
\end{abstract}

\section{INTRODUCTION}

The predominant pathogen isolated from the sputum of patients with cystic fibrosis (CF) is Pseudomonas aeruginosa (Wood, Boat and Doershuk, 1976). Once acquired, the organism is never eradicated, although it may disappear from the sputum temporarily after antibiotic treatment. In contrast to strains of $P$. aeruginosa from the environment or from routine clinical specimens, strains from CF sputum are usually sensitive to the bactericidal action of normal human serum (Høiby and Olling, 1977; Thomassen and Demko, 1981). This bactericidal activity is complement-mediated and initiated by natural opsonic antibodies, mainly of the IgM class (Young, 1972). Høiby and Olling (1977) noted that sera from three CF patients failed to kill strains of pseudomonas from the patient's own sputum although the strains were sensitive to normal human serum. Thomassen and Demko (1981) found a similar selective defect in five CF sera and noted that in two cases the CF sera could block the bactericidal activity of normal human serum against the autologous strains of pseudomonas. The aim of our study was to investigate further the bactericidal activity of CF serum against 
autologous and heterologous strains of pseudomonas, and to study the effect of CF serum on the bactericidal activity of normal human serum.

\section{MATERIALS AND METHODS}

Sera. Normal human serum (NHS) was obtained by pooling equal volumes of serum from five healthy volunteers. Cystic fibrosis serum (CFS) was obtained from two groups of CF patients who had typical clinical features of $\mathrm{CF}$ and a sweat sodium concentration of $>70$ mmols/L by pilocarpine iontophoresis (Gibson and Cooke, 1959). The first group consisted of 51 patients - 30 males and 21 females, age range $16-43$ years - all of whom were chronically infected by $P$. aeruginosa, which was isolated from every sputum sample for at least 6 months. The second group consisted of 10 patients - four males and six females, age range 16-49 years - who had never had $P$. aeruginosa isolated from their sputum and were considered to be free of this organism. Sera were stored in divided portions at $-20^{\circ} \mathrm{C}$ and used within 2 months.

Organisms. Six strains of $P$. aeruginosa of known sensitivity to NHS were used as a reference panel for comparing the bactericidal activity of patients' sera (table I). An environmental strain (0985), a strain from a patient with pneumonia secondary to carcinoma of the bronchus (2361) and two CF strains (002 and 003) were selected from strains sent to the Division of Hospital Infection, Central Public Health Laboratory, for serotyping. Strain 7/1 was the serum-sensitive variant of laboratory reference strain 7 . Sputum from CF patients was processed by routine methods and isolates of $P$. aeruginosa were serotyped with antisera to the 17 serotypes of the International Antigenic Typing Scheme (IATS) (Lányi and Bergan, 1978). Tryptone Soya Broth (Oxoid) was used throughout for liquid culture, and the solid medium was Oxoid Nutrient Broth No. 2 solidified with $1 \%$ (w/v) of agar (Oxoid, No. 1 ).

Serum sensitivity test. An 18-h broth culture of the test strain was diluted 1 in 100 in Hanks' balanced salt solution (Oxoid) and 50- $\mu$ l portions were added to equal volumes of NHS and to control tubes of Hanks' solution. Mixtures were incubated with gentle agitation at $37^{\circ} \mathrm{C}$ for $1 \mathrm{~h}$, and $20-\mu \mathrm{l}$ volumes were spotted on to agar plates. A further $20 \mu \mathrm{l}$ was added to $2 \mathrm{ml}$ of Hanks' solution and $20 \mu \mathrm{l}$ of this was sampled. Agar plates were incubated at $37^{\circ} \mathrm{C}$ for $18 \mathrm{~h}$ and the number of colonies counted. Serum-sensitive cultures were defined as those that yielded no more than 50 colonies from the $20 \mu \mathrm{l}$ of the undiluted sample, and for which the viable count was reduced by at least 1000 -fold compared with the control. Partially sensitive cultures gave counts of 51-200 colonies from the undiluted sample and, on dilution, growth was never confluent, in contrast to control samples. Resistant cultures always gave confluent growth from both dilutions of the test samples. All strains from CF patients were tested for sensitivity to NHS. Each CF serum was tested for bactericidal activity against the reference panel of pseudomonas strains and the strains isolated from that patient's sputum.

CF sera that failed to kill the autologous strains of pseudomonas were tested for their ability to inhibit the killing of those strains by NHS. Equal volumes $(50 \mu \mathrm{l})$ of CFS and NHS were pre-incubated at $37^{\circ} \mathrm{C}$ for $1 \mathrm{~h}$ and then $50 \mu \mathrm{l}$ of an 18 -h broth culture of pseudomonas diluted 1 in 100 in Hanks' solution was added. After incubation for a further $1 \mathrm{~h}, 20 \mu \mathrm{l}$ of the mixture was spotted on to an agar plate. A further $20 \mu \mathrm{l}$ was diluted serially in tenfold dilutions in Hanks' solution to 1 in 10000 , and $20 \mu \mathrm{l}$ of each dilution was plated to give a viable count. The same procedure was followed for control tubes in which the test organism was exposed to (1) NHS and Hanks' solution to confirm the serum-sensitivity of the organism; (2) CFS and Hanks' solution to monitor the bactericidal action of CFS alone; and (3) Hanks' solution alone to confirm the viability of the test organism. Sera from CF patients containing blocking factors were defined as those that did not kill the organism and also blocked the bactericidal action of NHS on that organism, such that the viable count from tubes containing both NHS and CFS was similar to that from the control tube in which the organism was held in Hanks' solution alone.

Absorption of sera. Equal volumes $(0.5 \mathrm{ml})$ of serum and packed cells harvested from the overnight growth of the absorbing strain on an agar plate were incubated at $37^{\circ} \mathrm{C}$ for $2 \mathrm{~h}$ and then at $4^{\circ} \mathrm{C}$ overnight. The suspension was centrifuged at $10000 \mathrm{~g}$ for $10 \mathrm{~min}$ and the serum was passed through a $0.45 \mu \mathrm{m}$ membrane filter (Millipore). Absorbed sera were then tested for residual bactericidal and blocking activity.

Characterisation of CF sera. Total haemolytic complement was measured by the method of 
Mayer (1961); immunoglobulins were measured by radio-immunoassay in a routine laboratory; ion-exchange chromatography was performed on a column $(1 \mathrm{~cm} \times 15 \mathrm{~cm})$ of DEAE cellulose equilibrated with $0.1 \mathrm{M}$ phosphate buffer $p \mathrm{H} 8$. The serum was dialysed against this buffer for 24 $\mathrm{h}$, and $1 \mathrm{ml}$ was processed through the column with $0.02 \mathrm{M}$ phosphate buffer. Fractions $(1 \mathrm{ml})$ were collected and tested with rabbit antisera to human immunoglobulin IgG and IgM (Seward, 1, Blackfriars Road, London SE1) by double-diffusion in agar gel (Ouchterlony, 1958).

Clinical assessment of patients. Respiratory function was assessed in an out-patient clinic on the day of sample collection; forced expiratory volume in one second $\left(F E V_{1}\right)$ and forced vital capacity (FVC) were measured on a Vitalograph spirometer and expressed as a percentage of predicted normal values (Cotes, 1979). An overall assessment of clinical condition was scored by the method of Shwachman and Kulczycki (1958) in which patients are scored from 0-25 points for each of four parameters: exercise tolerance, findings on physical examination of the chest, nutritional status and symptoms of malabsorption, and chest X-ray appearance; a score of less than 40 represents severe disease.

\section{RESULTS}

\section{Bactericidal activity of $C F$ sera against $P$. aeruginosa}

Sera from $20 \mathrm{CF}$ patients with pseudomonas infection and 10 patients who were not infected were tested for bactericidal activity against the reference panel strains (table I). Sera from both groups of patients were bactericidal for the strains sensitive to NHS, and strains resistant to NHS were also resistant to all but one of the CF sera.

TABLE I

Bactericidal activity of CF serum against strains of $P$. aeruginosa from various sources

\begin{tabular}{|c|c|c|c|c|}
\hline \multirow[b]{2}{*}{$\begin{array}{c}\text { Test } \\
\text { strain } \\
\text { no. }\end{array}$} & \multirow[b]{2}{*}{$\begin{array}{c}\text { Source } \\
\text { or } \\
\text { diagnosis }\end{array}$} & \multirow[b]{2}{*}{$\begin{array}{l}\text { Sensitivity } \\
\text { to NHS }\end{array}$} & \multicolumn{2}{|c|}{$\begin{array}{c}\text { Number of sera with bactericidal } \\
\text { activity }\end{array}$} \\
\hline & & & $\begin{array}{l}\text { Patients colonised } \\
\text { by } P \text {. aeruginosa } \\
(\mathrm{n}=20)\end{array}$ & $\begin{array}{l}\text { Patients free of } \\
P . \text { aeruginosa } \\
(\mathrm{n}=10)\end{array}$ \\
\hline 0985 & $\begin{array}{l}\text { Intensive } \\
\text { Care Unit } \\
\text { sink }\end{array}$ & + & 20 & 10 \\
\hline 2361 & Pneumonia & + & 19 & 10 \\
\hline $7 / 1$ & Laboratory & + & 20 & 10 \\
\hline 003 & CF & + & 20 & 10 \\
\hline 002 & CF & - & 1 & 0 \\
\hline 7 & Laboratory & - & 0 & 0 \\
\hline
\end{tabular}

NHS = normal human serum $;+=$ sensitive; $-=$ resistant.

One hundred and nineteen cultures of $P$. aeruginosa were isolated from the sputum of the first group of 51 patients, and $64(53.8 \%)$ were sensitive to NHS. Sera from all 51 patients were tested for activity against autologous cultures and of the 64 sensitive strains, 54 were killed by autologous CFS. Those strains that were resistant to NHS were also resistant to autologous CFS, but 10 NHS-sensitive strains derived from seven patients were resistant to CFS from those individuals (table II).

\section{Interference with NHS killing by CFS}

The seven patients' sera that were not bactericidal for autologous strains of pseudomonas were tested for blocking activity. Six of the seven sera neutralised the 
TABLE II

Bactericidal activity of $C F$ serum on autologous cultures of $P$. aeruginosa

\begin{tabular}{|c|c|c|c|}
\hline \multirow[b]{2}{*}{ Serum } & \multicolumn{2}{|c|}{ Number of strains } & \multirow[b]{2}{*}{ Total } \\
\hline & $\begin{array}{l}\text { fully } \\
\text { sensitive }\end{array}$ & $\begin{array}{c}\text { resistant or } \\
\text { partially sensitive }\end{array}$ & \\
\hline $\begin{array}{l}\text { Autologous } \\
\text { CF serum } \\
(\mathrm{n}=51)\end{array}$ & 54 & 65 & 119 \\
\hline $\begin{array}{c}\text { Pooled } \\
\text { normal } \\
\text { human } \\
\text { serum }\end{array}$ & 64 & 55 & 119 \\
\hline
\end{tabular}

bactericidal effect of NHS on eight strains of pseudomonas from those six patients, but one serum that failed to kill the corresponding strains had no effect on NHS. The blocking potency of these six sera was determined in serial doubling dilution tests and the blocking titre was defined as the highest dilution of CFS that resulted in a 1000 -fold increase in viable count compared with the control tube containing the test strain with NHS alone. Titres of $32,32,16,16,8$ and 4 were obtained for the sera from six patients (A-F). The neutralisation of NHS killing of sensitive strains was shown to be an active effect of CFS rather than a simple effect of dilution, by a parallel series of counts of the test organisms in NHS and Hanks' solution. NHS was bactericidal for all strains at a dilution of 1 in 4 . Table III shows the results obtained with serum from patient B.

\section{Studies of sera with blocking activity and the autologous strains}

Six CF sera with blocking activity had normal concentrations of complement, and normal or raised amounts of IgG, IgM and IgA. The sera were bactericidal for the four serum-sensitive strains of the reference panel (table I) and to three other NHS-sensitive, CF strains of pseudomonas. The eight strains of pseudomonas from

\section{TABLE III}

Effect of CF serum from patient $B$ on the bactericidal activity of NHS for P. aeruginosa strain $130 b^{*}$

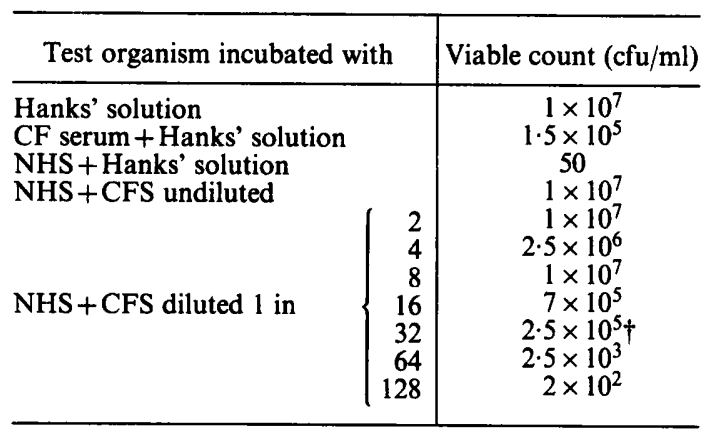

* Autologous strain; $\uparrow$ Titre $=32$.

NHS = normal human serum; $\mathrm{CFS}=$ cystic fibrosis serum from patient $B$. 
the six patients concerned were typical of isolates recovered from CF sputum (Penketh et al., 1983). Five grew as mucoid colonies and all showed multiple agglutination reactions with $\mathrm{O}$ antisera. These organisms were repeatedly retested for sensitivity to NHS and remained sensitive. They were also killed by other CF sera, both from patients colonised by pseudomonas $(n=12)$ and from those free of this organism $(n=6)$.

\section{Characterisation of blocking activity}

The sera and strains of the patients with a blocking titre were cross-tested for bactericidal and blocking activity. By definition, a serum containing a factor that interfered with the killing of a particular strain by NHS did not kill that strain. Table IV shows that blocking activity was selective for the patient's own strains in three cases (D, E and F) but cross-reactions were observed with the sera and strains of the other three patients (A, B, and C). Absorption of four CF sera with blocking activity by the appropriate strain of pseudomonas did not reduce the blocking effect when subsequently tested on autologous or heterologous strains.

TABLE IV

Pattern of blocking and bactericidal activity of sera from six CF patients for autologous and heterologous strains of $P$. aeruginosa

\begin{tabular}{|c|c|c|c|c|c|c|c|c|}
\hline \multirow[b]{2}{*}{$\begin{array}{l}\text { Serum from } \\
\text { CF patient }\end{array}$} & \multicolumn{8}{|c|}{$\begin{array}{c}\text { Blocking obtained with strain of } P \text {. aeruginosa } \\
\text { from stated patient }\end{array}$} \\
\hline & $\begin{array}{l}157 \mathrm{a} \\
\mathrm{A}\end{array}$ & $\stackrel{188}{A}$ & $\begin{array}{c}130 \mathrm{~b} \\
\mathrm{~B}\end{array}$ & 200 & $\stackrel{150 \mathrm{a}}{\mathrm{C}}$ & $\begin{array}{c}146 c \\
D\end{array}$ & $\stackrel{155 a}{E}$ & $\stackrel{154 b}{F}$ \\
\hline A & + & + & - & - & + & - & & - \\
\hline B & + & + & + & + & + & - & & - \\
\hline C & + & - & - & - & + & - & .. & + \\
\hline D & - & - & - & - & - & + & $\ldots$ & - \\
\hline $\mathrm{E}$ & - & - & - & - & $\ldots$ & - & + & - \\
\hline $\mathrm{F}$ & - & - & - & - & . & - & $\ldots$ & + \\
\hline
\end{tabular}

$+=$ presence of blocking factor (defective killing);

$-=$ absence of blocking factor (normal killing);

$\ldots=$ not done.

IgG-rich fractions of two CF sera obtained by ion-exchange chromatography interfered with the bactericidal action of NHS on autologous strains of pseudomonas, but fractions without IgG did not exhibit blocking activity (table V). No intrinsic bactericidal activity was found in these fractions, even in the presence of excess guinea-pig complement, when tested against autologous or reference strains.

\section{Clinical condition of patients with blocking factors in serum}

Clinical data for the six patients with blocking activity in serum are given in table VI. One patient (B) was in a very poor condition with a Shwachman score of 35 and has subsequently died. Three patients had moderately severe disease with scores of $50-55$, and two were in good condition with scores of 75 . There was no correlation 
TABLE V

Interference with bactericidal action of NHS on autologous strains of pseudomonas by two CF sera and fractions of those sera obtained by ion-exchange chromatography

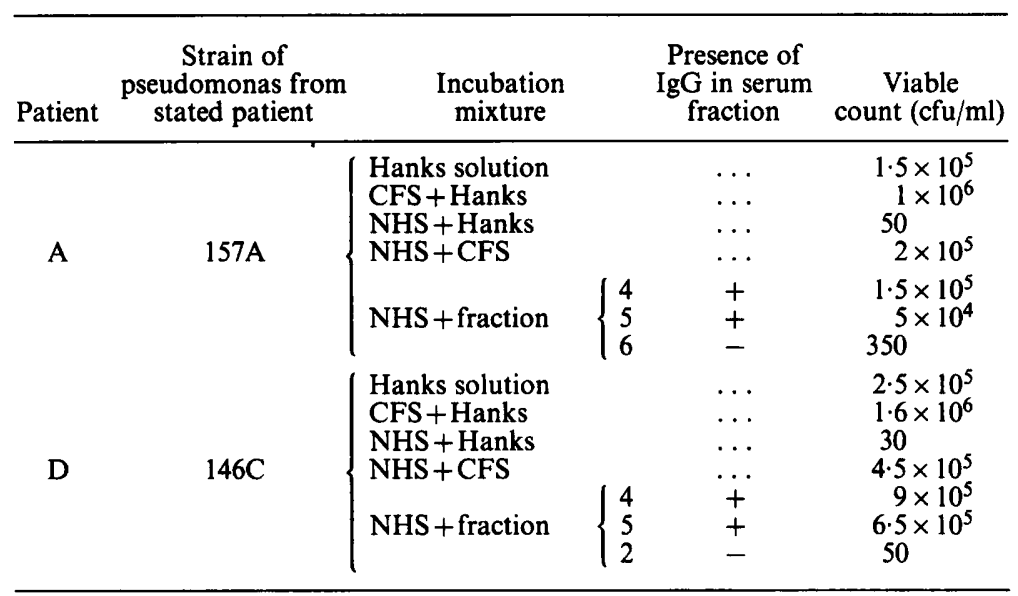

NHS $=$ normal human serum; $\mathrm{CFS}=$ cystic fibrosis serum.

TABLE VI

Clinical data of six CF patients with blocking activity in serum

\begin{tabular}{|c|c|c|c|c|c|c|c|}
\hline \multirow[b]{2}{*}{ Patient } & \multirow[b]{2}{*}{ Sex } & \multirow[b]{2}{*}{ Age } & \multicolumn{2}{|c|}{$\begin{array}{l}\text { Percentage of predicted normal } \\
\text { value* obtained in test of }\end{array}$} & \multirow{2}{*}{$\begin{array}{c}\text { Clinical } \\
\text { score }^{*}\end{array}$} & \multirow{2}{*}{$\begin{array}{l}\text { Blocking } \\
\text { factor } \\
\text { titre }\end{array}$} & \multirow{2}{*}{$\begin{array}{c}\text { Duration of } \\
\text { colonisation } \\
\text { by } \\
\text { pseudomonas }\end{array}$} \\
\hline & & & $\mathrm{FEV}_{\mathbf{l}}$ & FVC & & & \\
\hline $\begin{array}{l}\text { A } \\
\text { B } \\
\text { C } \\
\text { D } \\
\text { E } \\
\text { F }\end{array}$ & $\begin{array}{c}\mathrm{M} \\
\mathbf{F} \\
\mathbf{M} \\
\mathrm{F} \\
\mathrm{M} \\
\mathrm{M}\end{array}$ & $\begin{array}{l}16 \\
31 \\
24 \\
22 \\
20 \\
24\end{array}$ & $\begin{array}{l}45 \\
26 \\
18 \\
23 \\
24 \\
46\end{array}$ & $\begin{array}{l}66 \\
32 \\
35 \\
27 \\
39 \\
61\end{array}$ & $\begin{array}{l}75 \\
35 \\
50 \\
50 \\
55 \\
75\end{array}$ & $\begin{array}{r}16 \\
32 \\
8 \\
4 \\
16 \\
32\end{array}$ & $\begin{array}{l}3 \\
1 \cdot 5 \\
9 \\
3 \dagger \\
14 \\
11\end{array}$ \\
\hline
\end{tabular}

* See Methods;

$+=$ at least 3 years but no record of first isolation of organism.

between blocking factor titre and clinical score, respiratory function or duration of colonisation by pseudomonas.

\section{Discussion}

$P$. aeruginosa strains isolated from the environment and from most clinical specimens are serum resistant (Young, 1972) although some strains, especially from chronic infections, may be serum sensitive. In cystic fibrosis, however, the majority of strains are serum sensitive (Høiby and Olling, 1977; Thomassen and Demko, 1981; Penketh et al., 1983). Furthermore, a relative inability of some CF sera to kill autologous strains of $P$. aeruginosa was described by Høiby and Olling (1977), who found that the sera of 3 out of 17 patients $(17 \cdot 6 \%)$ were defective. Thomassen and 
Demko (1981) found a similar defect in the sera of 5 out of 42 patients $(11.9 \%)$ and noted that these five patients were in a poor clinical condition. In two cases these workers demonstrated that CF sera could block the bactericidal action of NHS against the autologous strains. The present study showed that CF sera were able to kill strains of pseudomonas from the environment and from other patients with or without cystic fibrosis. A small number of patients -7 out of 51 individuals $(13.7 \%$ )- had a selective inability to kill autologous strains of pseudomonas that were sensitive to normal human serum and to serum from other CF patients. A factor that could be titrated was found in six CF sera and blocked the bactericidal action of NHS on the patient's own strain of pseudomonas. This factor was associated with the IgG fraction of serum but was not removed from the serum by absorption with the appropriate pseudomonas strain. The presence of blocking factors in serum did not relate to the clinical condition of the patient in this small group, unlike the findings of Thomassen and Demko (1981). Because pseudomonas remains localised within the respiratory tract in CF, the presence of serum blocking antibody is unlikely to be important clinically. It would be interesting, however, to look for similar blocking antibodies in bronchial secretions.

In CF patients with blocking factors, the pseudomonas strain has become uniquely 'resistant' to the serum of its host, and the possible mechanisms are limited. A change in the bacterial antigens would affect the sensitivity of the organism to other sera, but in the present study organisms remained sensitive to all other sera. The six CF sera with blocking factors were bactericidal for other sensitive strains, so deficiency of lytic antibody or complement is unlikely. Total complement levels in these sera were normal and the amounts of immunoglobulins were normal or raised, as is common in cystic fibrosis. A possible explanation may be the presence of a blocking antibody that arises as a consequence of long-standing bacterial colonisation.

Blocking factors were demonstrated in the sera of two patients with chronic pseudomonas infection (not CF) by Guttman and Waisbren (1975). This was identified as IgG which was absorbed from the serum by the autologous strain. These authors suggested a mechanism of competitive inhibition by this IgG of natural lytic IgM binding to the bacterial cell surface, bound IgG being unable to fix complement as successfully as multivalent IgM. In that study, one serum was tested against a panel of strains representing different serotypes and the pattern of the bactericidal activity of the patient's serum was the same as that observed with NHS. Killing of other sensitive strains was not blocked by the serum even when the strains were of the same serotype. The authors concluded that the antigen-binding site of the blocking factor was not that recognised by rabbit typing sera. This mechanism does not seem to apply to the blocking factors in CF serum as they were not always strain specific and were unaffected by absorption with the pseudomonas strain, and probably, therefore, did not bind to a cellular site. Thomassen and Demko (1981) also stated that absorption with the autologous strain failed to remove blocking activity. An alternative explanation is that the IgG blocking antibody is directed against the naturally occurring bactericidal IgM described by Young (1972). It implies that within the natural bactericidal IgM of the CF patient there is a sub-group specific to the dominant strain of pseudomonas in that patient, and that blocking IgG antibody affects only this particular sub-group of IgM. 
We are most grateful to Mr D. E. Roberts and Mrs B. Hyde for expert technical help; Dr B. Cohen for advice; and Dr J. Grange for laboratory facilities; the Biochemistry Department, Brompton Hospital, for immunoglobulin assays; and Miss S Hockley for secretarial assistance. ARLP is supported by the Augustus and Frances Newman Foundation.

\section{REFERENCES}

CoTES, J. E. 1979. Lung Function: assessment and application in medicine, 4th ed., Blackwell, Oxford.

GiBson, L. E. AND CoOKe, R. E. 1959. A test for concentration of electrolytes in sweat in cystic fibrosis of the pancreas utilising pilocarpine by iontophoresis. Pediatrics, 23, 545-549.

Guttman, R. M. AND WaisBren, B. A. 1975. Bacterial blocking activity of specific IgG in chronic Pseudomonas aeruginosa infection. Clinical and Experimental Immunology, 19, 121-130.

Høiby, N. AND Olling, S. 1977. Pseudomonas aeruginosa infection in cystic fibrosis. Bactericidal effect of serum from normal individuals and patients with cystic fibrosis, on $P$. aeruginosa strains from patients with cystic fibrosis or other diseases. Acta Pathologica et Microbiologica Scandinavica, Sect. C, 85, 107-114.

LÁNYI, B. AND BERGAN, T. 1978. Serological characterisation of Pseudomonas aeruginosa. In Methods in microbiology, vol. 10, edited by T. Bergan and J. R. Norris. Academic Press, London, pp. 93-168.

MAYER, M. M. 1961. Complement and complement fixation. In Experimental immunochemistry, 2nd ed., edited by E. A. Kabat and M. M. Mayer, C. C. Thomas, Springfield, IL, p. 133.

OUCHTERLONY, O. 1958. Diffusion-in-gel methods for immunological analysis. In Progress in allergy, vol. 5 edited by P. Kallos, Karger, Basel, p. 1-78.

Penketh, A. R. L., Pitt, T. L., Roberts, D., Hodson, M. E. and Batten, J. C. 1983. The relationship of phenotype changes in Pseudomonas aeruginosa to the clinical condition of patients with cystic fibrosis. American Review of Respiratory Diseases, 27, 605-608.

ShwaChMAN, H. AND KulCZYCKI, L. L. 1958. Long-term study of 105 patients with cystic fibrosis: studies made over a 5 to 14 year period. American Journal of Diseases of Children, 96, 6-15.

Thomassen, M. J. AND Demko, C. A. 1981. Serum bactericidal effect on Pseudomonas aeruginosa isolates from cystic fibrosis patients. Infection and Immunity, 33, 512-518.

Wood, R. E., Boat, T. F. ANd Doershuk, C. F. 1976. Cystic Fibrosis: State of the Art. American Review of Respiratory Diseases, 113, 833-878.

YouNG, L. S. 1972. Human immunity to Pseudomonas aeruginosa. II. Relationship between heat-stable opsonins and type specific lipopolysaccharides. Journal of Infectious Diseases, 126, 277-287. 